\title{
STRATEGI PROGRAMMING PADA PROGRAM "HAFIZ INDONESIA 2015" RCTI UNTUK MEMPEROLEH RATING SHARE TINGGI
}

\author{
Haronas Kutanto \\ Fakultas Ilmu Komunikasi Universitas Budi Luhur \\ haronas.kutanto@budiluhur.ac.id \\ Diajukan: 13-11-2017; Direview: 13-11-2017; Diterima: 23-12-2017;
}

\begin{abstract}
Hafiz Indonesia's television program features talented children in memorizing the Qur'an without any scenarios or scripts. The purpose of this research is to know the Planning Programming strategy and Packaging Program of Hafiz Indonesia 2015 in RCTI, in order to get high share rating. This research is using qualitative and descriptive and Fred Wibowo's production concept. The results of programming strategy in production concept are stripping strategy on big audience, checker boarding strategy when the number of audience is decreasing, strategy of tent poling to introduce new program. The planning process of Hafiz Indonesia program is carried out in a mutual way starting from the analyst program. Pre-production activities will be aired and begun by casting ideas or ideas into an outline containing an event's program. The selected resource is the person who has the credibility and knows exactly about the topic to be discussed. The result of this research is expected to give a constrictive contribution to the development and assessment of communication science generally and practically.
\end{abstract}

Keywords: Strategy Programming, Hafiz Indonesia, RCTI, Planning, Rating Share

\begin{abstract}
Abstrak
Program televisi Hafiz Indonesia menampilkan anak-anak muda berbakat dalam menghafal Al-Quran. Tujuan Penelitian ini mengetahui Strategi Programing Pengemasan Program Acara Hafiz Indonesia 2015 di RCTI guna memperoleh rating share tinggi. Metode penelitian ini dengan menggunakan kualitatif, Deskriptif teori yang di gunakan yaitu Konsep Produksi Fred Wibowo. Hasilnya yaitu strategi stripping pada saat jumlah audiensbesar, strategi checker boarding pada saat jumlah audiens mengalami penurunan, strategi tentpolinguntuk memperkenalkan program barunya. Proses perencanaan program Hafiz Indonesia dilakukan secara bersamasama, dimulai dari program analyst. Kegiatan pra produksi akan ditayangkan dan dimulai dengan penuangan ide atau gagasan ke dalam outline yang berisikan gambaran program suatu acara. Narasumber yang dipilih adalah orang yang memiliki kredibilitas dan mengetahui dengan pasti mengenai topik yang akan dibahas. Secara teoritis hasil penelitian ini diharapkan dapat memberikan kontribusi yang konstruktif bagi pengembangan dan pengkajian ilmu komunikasi umumnya, secara praktis ini diharapkan dapat menjadi bahan masukan bagi pihak-pihak yang berkepentingan.
\end{abstract}

Kata Kunci : Strategi Programming, Hafiz Indonesia, Perencanaan, RCTI, Rating Share

\section{PENDAHULUAN}

$\mathrm{F}$ enomena melalui ajang kompetisi menghafal Al-Quran Hafiz Indonesia pemirsa televisi dapat melihat kemampuan luar biasa dari anak-anak kecil Indonesia yang berjuang menjadi seorang Hafiz Indonesia muda. Program ini juga menarik perhatian publik hingga menjadikan Hafiz
Indonesia sebagai Program Acara Ramadhan terbaik ajang KPI-MUI Award 2015 (www.kpi. go.id)dan Program Acara Ramadhan terfavorit di ajang Panasonic Gobel Awards 2015. Hafiz Indonesia adalah program islami dengan menandingkan anak-anak berusia 3-7 tahun yang hafal Qur'an. Program ini merupakan salah satu 
andalan RCTI di bulan Ramadhan. Persaingan program acara televisi yang sangat ketat antara stasiun televisi satu dengan stasiun televisi lainnya, membuat setiap programacaranyajuga harus mempunyai kelebihan dan keunggulan untuk bisa mempertahankan pemirsa setia program acara tersebut, program acara "Hafiz Indonesia" menjadi program acara pioner dan menjadi satu-satunya program unggulan reality showtalent search yang melombakan anak-anak penghafal Al-Qur'an. Acara ini tidak di sertai dengan dukungan polling sms untuk penilaian peserta, hanya dewan jurilah yang berhak menilai kemampuan dari para peserta, salah satu yang menjadi penilaian juri diantaranya adalah makhrajul huruf tajwid dan kelancaran para pesertadan program cara ini dikemas dengan estetika yang elegan dan kental dengan nuansa islami.

"Hafiz Indonesia" merupakan salah satu program acara di televisi yang mempunyai keunikan tersendiri dari program acara lainnya, selain melombakan anak - anak kecil yang berumur 3-7 tahun, seperti Adi salah satu peserta yang berumur 3 tahun yang pernah tampil para peserta juga harus memenuhi persyaratan mewajibkan menghafal minimal 30 juz dan di antaranya juga jus 29. Selain itu, Kelebihan "Hafiz Indonesia" ini memiliki sistem perlombaan lebih jelas dan gameslebih variatif, set dan grafis sudah lebih dinamis, konten peserta sangat kuat, bintang tamu internasional. Dukungan terhadap televisi yang baik sangat penting untuk mengimbangi program-program yang dapat merusak moral anakanak. Kita dapat mengapresiasi dan memberikan dukungan untuk keberlangsungan program acara tersebut via social media dengan komentar/ testimoni positif mengenai penayangan "Hafiz Indonesia".Penayangan program acara "Hafiz Indonesia" dimulai pada awal bulan Ramadan dan disiarkan setiap sore pukul 14.30 WIB. Hafiz Indonesia formasi awal di pandu oleh Irfan Hakim sebagai Presenter atau presenter dan beberapa juri yang berkompenten dibidangnnya, seperti Ustad. Bachtiar Nasir Ustad Riza Muhammad, Ustadah Lulu Susanti dan Ust. Caem Maulana dan juga Alvin Firmansyah (10 tahun) Hafiz Indonesia cilik hafal 17 juz.
Dalam mengasilkan penilaian positif dari masyarakat terhadap program acara televisi tidaklah lepas dari sebuah perencanaan dan pengemasan program yang terkonsep melalui proses kreatifitas yang nantinya akan mempengaruhi rating yang di hasilkan serta penilaian program yang berkualitas di benakpenonton yang menikmatinya. Strategi program televisi di perlukan agar setiap program yang di tayangkan mencapai hasil yang optimal atau perencanaan konsep yang matang oleh seluruh tim produksi (Produser) dalam mengasilkan pengemasan program yang berkualitas, mendidik dan menghibur. Mendapatkan data rating penonton yang bagus, serta kepuasaan dalam menghadirkan sebuah tayangan yang dinikmati banyak audiensatau masyarakat.

Rating merupakan faktor utama yang menjadi tolak ukur keberhasilan dari sebuah program acara televisi.Walaupun program acara ini masih memiliki kekurangan seperti sistem perlombaan dan sistematika tayang yang masih belum sejalan, kemudian materi games dan treatment yang masih belum variatif, wadrobe peserta juri, Presenter yang kurang bagus atau monoton, set dan grafis belum terkesan dinamis, Jadwal ustad bentrok dengan jadwal syuting,penonton lebih banyak dari kalangan ibu - ibu pengajian dan seharusnya lebih variatif, penampilan bintang tamu yang menyanyi dan pada akhirnya tidak tayang. Programming dalam televisi adalah suatu bagian yang paling penting, ibaratnya adalah jantung dari suatu televisi, karena apa yang dijual dan diberikan pada masyarakat adalah program. Melalui program yang disajikan tersebut maka ciri khas dan kualitas stasiun televisi ditentukan.

Programming dalam televisi adalah suatu bagian yang paling penting, ibaratnya adalah jantung dari suatu televisi, karena apa yang dijual dan diberikan pada masyarakat adalah program. Melalui program yang disajikan tersebut maka ciri khas dan kualitas stasiun televisi ditentukan. Dapat dilihat pula dalam programming, stasiun televisi mampu menentukan mana program unggulannya yang akan tayang di slot waktu Prime Time dan mana program yang akan menjadi pembuka pada slot waktu Prime Time sehingga mampu menggiring audien menuju tayanganunggulan (Hertika Yudha Pratiwi:2004 
FISIP UI).

Penayangan "Hafiz Indonesia" selalu mendapatkan ratingterbaik kategori program special Ramadhan.Acara ini sangat menginspirasi dan memotivasi anak-anak diseluruh nusantara untuk mengikuti ajang kompetisi penghafal AlQur'an tersebut. Acara ini tidak pernah sepi penonton, tidak hanya anak-anak saja yang turut hadir menyaksikan acara tersebut, bahkan orang dewasapun turut meramaikan acara ini. Bukti keberhasilan dan kesuksesan program tersebut, peserta audisi dari tahun ke tahun, banyak mengalami perubahan dari jumlah peminat untuk mengikuti acara Hafiz Indonesia. Artinya program special Ramadhan ini sangat memberikan edukasi positif terhadap masyarakat terutama anak-anak Indonesia. Animo masyarakat tentang acara ini lebih merasa tertantang kepada putera-puterinya yang ingin atau menginginkan agar menjadi bagian dari Hafiz Indonesia, tentu perjuangan tidaklah mudah bagi dewan juri untuk memberikan kesempatan sehingga hanya anak-anak berpotensilah yang mendapatkan peluang untuk menjadi bagian dari anak- anak Hafiz Indonesia. Penelitian ini merumuskan permasalahan tentang bagaimana Strategi Programming dalam Pengemasan Program Acara "Hafiz Indonesia 2015" untuk memperoleh Rating Share Tinggi"

\section{LITERATUR DAN METODOLOGI}

Televisi adalah bagian yang menyatu dengan kehidupan sehari-hari dan menjadi sumber umum utama dari sosialisasi dan informasi bagi masyarakat. Bagi Gerbner, dibandingkan media massa yang lain, televisi mendapat tempat tersendiri. Demikian signifikan dalam kehidupan sehari-hari sehingga mendominasi "lingkungan simbolik" kita, dengan cara menggantikan pesannya tentang realitas pengalaman pribadi dan sarana mengetahui dunia lainnya (Mc Quail, 1996:254). Selain itu, televisi telah menjadi bagian dari kebudayaan audio visual, merupakan medium paling berpengaruh dalam membentuk kepribadian masyarakat yang luas, hal ini disebabkan oleh satelit dan pesatnya perkembangan jaringan televisi yang menjangkau masyarakat hingga ke wilayah terpencil (Wibowo, 2007, 17).
Dalam perkembanganya televisi memliki program program unggulan yang memanjakan pemirsanya sehingga pemirsanya menjadi malas untuk beranjak dari depan televisi. Format acara televisi adalah sebuah perencanaan dasar dari suatu konsep acara televisi yang akan menjadi landasan kreatifitas dan desain produksi yang akan terbagi dalam berbagai kriteria utama yang disesuaikandengan tujuan dan target pemirsa acara tersebut (Naratama, 2006 : 63). Program merupakan ujung tombak sebuah stasiun televisi yang langsung bersentuhan dengan pemirsa, karena itulah diperlukan pengaturan program yang tepat Programing dapat didefinisikan sebagai strategi penggunaan program yang sudah tersusun yang dirancang untuk menarik audiensyang telah ditentukan.Programing yang bagus menjadi sebuah landasan dasar dalam memenangkan persaingan. Dengan didukung oleh strategi yang meliputi perencanaan (planning) dan pengarahan (directing) terhadap segala kegiatan operasional seperti pengaturan jaringan siaran dan penyusunan program- program acara yang sedemikian rupa sehingga tepat sasaran kepada target audiensce yang tetap ditetapkan. Hal ini sangat penting sifatnya mengingat perkembangan televisi lokal di daerah semakin banyak di tengah maraknya stasiun televisi nasional menayangkan tayangan program acara yang seragam.

Proses produksi program televisi terdiri atas tiga bagian utama; yaitu Tahapan pembahasan dan pencarian ide, gagasan, perencanaan, pemilihan talent, lokasi dan kerabat kerja. Pada tahapan ini yang bertanggung jawab adalah eksekutif produser, produser, program director dan tim kreatif (Latief, Utud: 2015, 148). Dimulai dari pembahasan ide (brainstorming), mencari dan mengelola gagasan yang akan dituangkan dalam bentuk proposal, penulisan rundown, naskah dan schedule program.; Setelah melewati proses praproduksi yang menghasilkan outline produksi seperti rundown script. Rundown script itulah yang akan dijadikan acuan eksekusi produksi (Shooting) menyesuaikan konsep dan format produksi. (Latief, Utud: 2015,152) Mengubah naskah menjadi bentuk audio video, yang berupa pelaksanaan perekaman gambar (tapping) atau siaran langsung (live).; 
Pasca Produksi (Post Production) adalah tahap akhir sebelum on air (Latief, Utud: 2015, 155). Tahapan setelah proses produksi pengambilan sebelum gambar selesai dan dinyatakan aman, master atau materi video tersebut masuk pada tahap editing, dalam hal ini penyuntingan gambar atau pengemasan akhir, hingga dinyatakan siap untuk ditayangkan. Tentunya materi video yang akan ditayangkan telah dievaluasi (playback) dan dinyatakan aman oleh produser program acara.

Menurut Jauch dan Glueck (1998:6) strategi adalah rencana yang disatukan menyeluruh secara terpadu yang mengkaitkan keunggulan strategi yang dimiliki oleh masing-masing perusahaan serta tantangan lingkungan dan dirancang untuk memastikan bahwa tujuan serta misi perusahaan dapat tercapai melalui pelaksanaan yang tepat oleh perusahaan.Suwarsono (2008:6) juga mengemukakan pendapatnya tentang strategi, yaitu usaha managerial untuk menumbuhkembangkan kekuatan perusahaan dalam mengeksploitasi peluang bisnis yang muncul guna mencapai tujuan perusahaan yang telah ditetapkan sesuai dengan misi yang telah ditentukan strategi mencerminkan kesadaran organisasi atau perusahaan mengenai bagaimana, kapan, dan dimana organisasiatau perusahaan harus bersaing dan organisasi atau perusahaan apa yang menjadipesaingnya.
Peneliti menggunakan pendekatan paradigma Post - Positivisme untuk mengetahui Strategi Programing Perencanaan, pengemasan dan proses produksi pada program acara Hafiz Indonesia 2015. paradigma post - posivisme aliran ini menegaskan arti penting dari hubungan interaksi antara peneliti dengan objek yang bersifat netral agar tingkat subyektifitas dapat di kurangi, dengan menitikberatkan pada observasi dan wawancara dengan pihak pihak yang terlibat dalam proses pembuatan program Hafiz Indonesia 2015,

\section{TEMUAN DAN DISKUSI}

Strategi Program acara "Hafiz Indonesia" ditayangkan setiap awal Ramadan juli 2015 dan disiarkan setiap sore pukul $14.30-15.00$ WIB. Acara ini banyak mendapat animo masyarakat yang positif seperti yang di ungkapan oleh Produser Hafiz Indonesia:

"Berawal dari khayalan dan keikhlasan dalam bekerja, acara ini menjadi sebuah kenyataan dan dampak yang besar, program ini seperti virus positif yang menyebar cepat dan dapat memotivasi anak-anak, orangtua, bahkan diri kita sendiri. program ini sebagai tamparan bagi para orang tua, anak-anak usia 3 - 7 tahun saja dapat menghafal Al-Qur'an dengan baik, sementara usia dewasa yang notabenya lebih

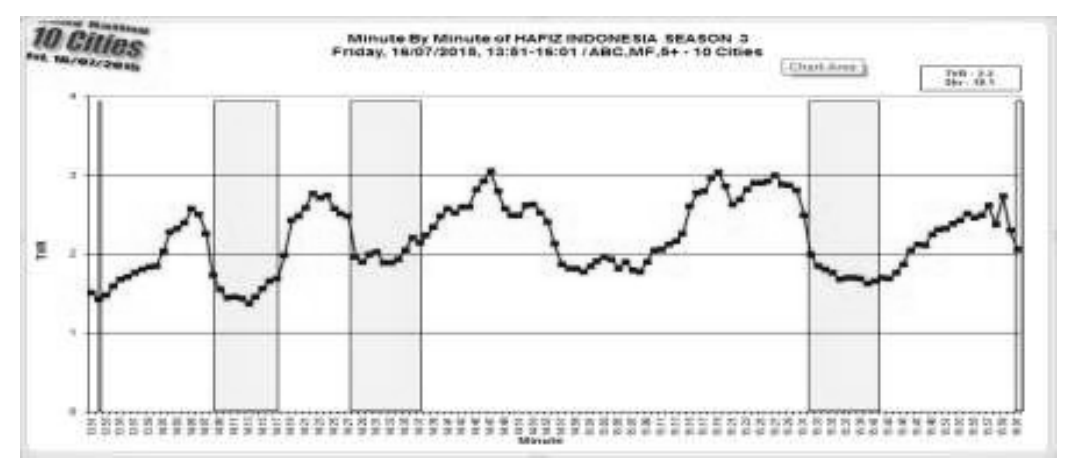

Gambar 1. Hafiz Vs Competitor 1

tua dari anak-anak tapi tidak bisa menghafal AlQur'an dengan baik, dan tentunya membawa dampak yang baik bagi anak-anak Indonesia". Hal itu merupakan kesuksesan para produser bersama rekan atau struktur kerabat kerja Hafiz Indonesia 2015. Keberhasilan tersebut tidak jauh beda dari strategi yang dia gunakan, dimana RCTI menggunakan strategi stripping yaitu strategi untuk menjaga jumlah audiens dengan menempatkan program yang sama pada slot waktu yang sama selama hari berturut-turut.

Dapat dilihat (tabel 1) pada waktu Early Morning pukul 02.00 WIB -04.59 WIB ( audiens Kelas A-B, jumlah audiens sedikit) terdapat 
Program Assalamualaikum Ustad. Lalu waktu Morning Time yaitu pukul 05.00 08.59 WIB pada hari senin- jumat (audiens Kelas A-B, semua umur atau jumlah audiens banyak). RCTI menayangkan Go Spot pada pukul 06.00 WIB, Dahsyat pada puku107.00 WIB.Kemudian pada waktu Day Time yaitu pukul 09.00 WIB - 11.59 WIB (audiens kelas C,D,E, anak- anak, perempuan, semua umur atau jumlah audiens sedikit) RCTI meletakkan INTENS pada pukul 10.30, dilanjutkan dengan SILET pada pukul 11.00WIB. Selanjutnya pada waktu Noon Time pukul 12.00 WIB -15.59 WIB hari senin- minggu (audiens kelas C,D,E, anak -anak, perempuan, semua umur.jumlah audiens sedikit) terdapat acara Seputar Indonesia Siang pada pukul 12.00 WIB, selanjutnya program Buka-Bukaan pada pukul 12.30 WIB.Sedangkan pada waktu Early Prime Time 18.00 WIB -18.59 WIB dan Central Prime Time (audiens kelas
A,B,C,D,E, semua audiens atau jumlahnya besar) RCTI menayangkan program drama sinetron padapukul20.00 hingga waktu Late Prime Time 21.00 WIB - 22.29 WIB (audiens kelas A,B,C,D,E, semua audiens atau jumlah audiens besar)

Strategi lainnya yang digunakan oleh RCTI adalah tentpoling yaitu langkah perencanaan slot waktu bagi program acara yang baru, sebelum dan setelah program ungulan yang mempunyai audienscukup besar dengan menayangkan Fortune Cookies dan East Java Tournament 2013 pada pukul 17.00 Evening Time 16.00 WIB 17.59 WIB (audiens kelas A,B,C,D,E, anak-anak, perempuan,semua umur atau audiens mulai besar) sebelum penayangan program unggulan pada waktu Prime Time. Untuk tayangan yang tayang setelah waktu prime time, RCTI menggunakan strategi checkerboarding yaitu strategi untuk meraih jumlah audiens dengan menempatkan

Tabel 1. Audiensce Class Juni - Juli 2015

(Sumber: RCTI 2015)

\begin{tabular}{llllllll}
\hline & Senin & Selasa & Rabu & Kamis & Jumat & Sabtu & Minggu \\
\hline \multirow{2}{*}{04.00} & Liga & Asw. & Asw. & Asw. & Asw. & Asw. & Asw. \\
& BBVA & Ustad & Ustad & Ustad & Ustad & Ustad & Ustad \\
\hline 06.00 & Go Spot & Go Spot & Go Spot & Go Spot & Go Spot & Go Spot & Go Spot \\
\hline 07.30 & Dashyat & Dashyat & Dashyat & Dashyat & Dashyat & Dashyat & Dashyat \\
\hline 10.30 & Intens & Intens & Intens & Intens & Intens & Intens & Intens \\
\hline 11.00 & Silet & Silet & Silet & Silet & Silet & Silet & Silet \\
\hline 12.00 & Sp.Siang & Sp.Siang & Sp.Siang & Sp.Siang & Sp.Siang & Sp.Siang & Sp.Siang \\
\hline \multirow{2}{*}{13.50} & Hafiz & Hafiz & Hafiz & Hafiz & Hafiz & Hafiz & Hafiz \\
& Indonesia & Indonesia & Indonesia & Indonesia & Indonesia & Indonesia & Indonesia \\
\hline \multirow{2}{*}{18.00} & Anak & Anak & Anak & Anak & Anak & Anak & Anak \\
& Manusia & Manusia & Manusia & Manusia & Manusia & Manusia & Manusia \\
\hline \multirow{2}{*}{20.00} & Tukang & Tukang & Tukang & Tukang & Tukang & Tukang & Tukang \\
& Bubur naik & Bubur naik & Bubur naik & Bubur naik & Bubur naik & Bubur naik & Bubur naik \\
& Haji & Haji & Haji & Haji & Haji & Haji & Haji \\
\hline
\end{tabular}

program yang berbeda pada slot waktu yang sama setiap harinya. Pada waktu night time22.30 WIB -23.59 WIB (audiens kelas A,B, laki-laki jumlah audiens mulai menurun) diisi dengan tayangan berformat Film Box Office.

Materi sangat penting untuk menentukan program acara yang akan di buat, tanpa ada materi, program tidak akan terlaksana dengan baik seperti ungkapan Produser Hafiz Indonesia. Perjuangan seorang produser yang di sampaikan di atas, tentu tidak mudah karena mencentuskan ide itu memang mudah, tetapi harus memperhatikan point - point yang di anggap bagian dari ide yang di cetuskan. Ketika referensi yang di berikan oleh pihak programing dan key word nya itu merupakan hantaran untuk membuat sebuah program yang menarik yang bertemakan anak-anak kecil islami. Awal mulanya ketika konsep itu terbentuk, banyak revisi yang dihadapi oleh seorang produser terutama pada segmentasi yang kurang jelas, tidak sesuai dengan keinginan programing, dan sempat bingung dengan keinginan programing. 
OpeningAct: Qori, VT Pretitle 28, Present ke-28 besarfinalis, Present Juri 28 peserta dibagi menjadi 2 kelompok (@14 orang).

Adapun nama-nama timnya adalah: Zaid bin Tsabit, Ubay binKa'ab, Estafet surat perkelompok, Chit chat dan eksplor bakat individu perkelompok. Tagline yang tertulis dalam auidisi, para masyarakat Indonesia yang merasa bahwa anaknya memiliki kemampuan untuk mengahafal tentu saja berusaha untu mendaftarkan anak-anaknya, apa lagi acara ini sangat mengedukasi bagi anakanak Indonesia, setidaknya kurang permainan game yang dia lakukan setiap hari, ini merupakan modal untruk para ibu-ibu agar memberikan untuk

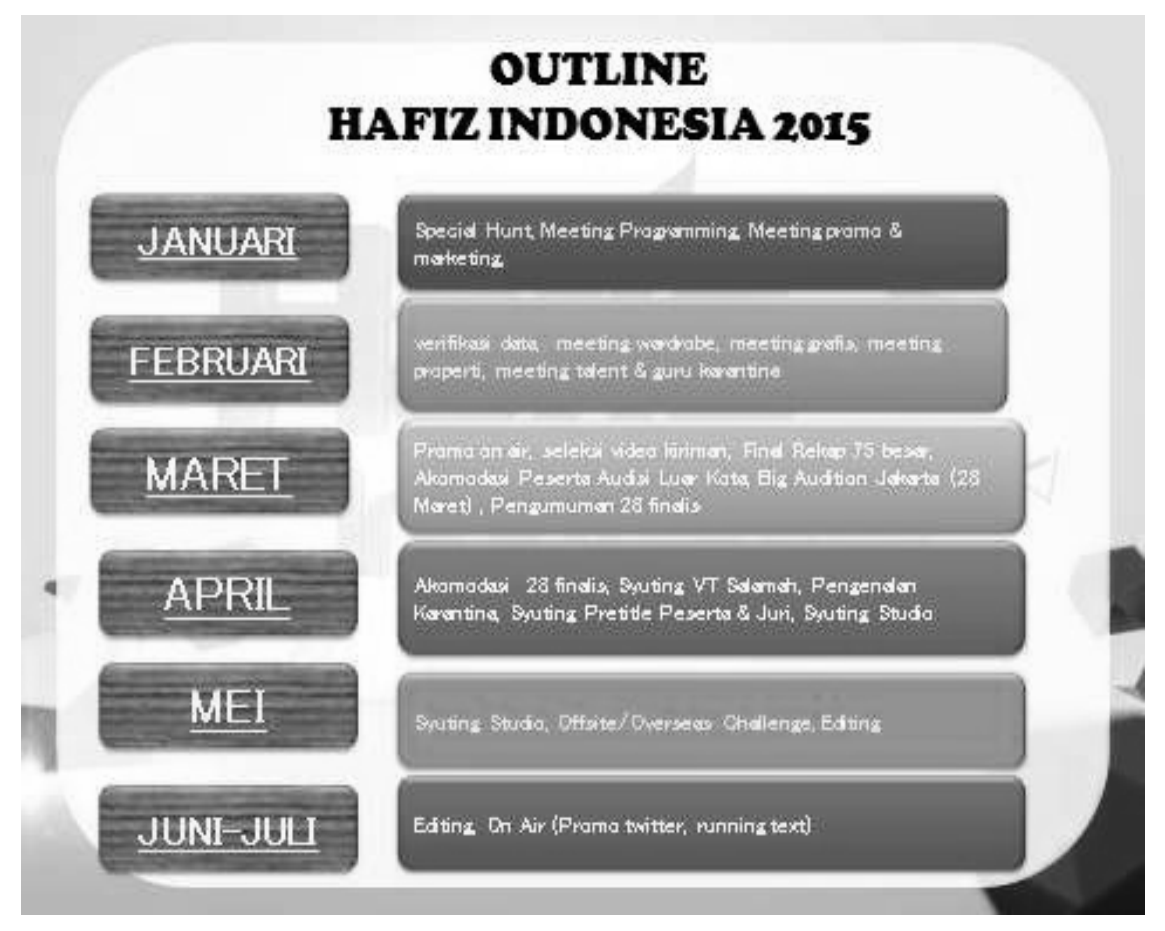

Gambar 2. Outline Hafiz Indonesia

(Sumber: Produser Hafiz Indonesia)

mengambil peluang yang diberikan oleh RCTI.

Outline dalam sebuah acara sangat penting agar acara yang di susun atau direncanakan dapat terlaksana sesuai dengan jadwal yang akan di tayangkan. Gambar 2 merupakan outline dari perencanaan Program Hafiz Indonesia yang merupakan bagian program acara bertahap.

Memanfaatkan momen tahunan ini, biasanya stasiun televisi swasta maupun pemerintah sibuk mengharapberkah. Sayangnya, berkah yang awalnya bermakna ziyaadatul khair (bertambahnya kebaikan) banyak mengalami penyempitan makna. Bahkan implementasi di lapangan sudah tidak jarang melenceng dari makna "kebaikan" yang hakiki. Kita ambil contoh, program sahur di beberapa stasiun televisi.

Presenter secara umum diartikan sebagai orang yang memegang acara suatu tertentu.
KeberadaanPresenter biasanya identik dengan acara yang dibawakannya. Dengan demikian, selain jenis acara figur Presenter yang bersangkutan akan memegang peranan penting dan kehadiran seorang Presenter yang berkarakter akan menjadi daya tarik suatu acara .pertimbangan dan pemilihan Presenter tidak hanya berdasarkan karena kecantikannya atau popularitasnya tetapi intergritas dan karakternya. Produksi (eksekusi program outdoor atau indoor) kegiatan produksi antara lain; jika semua persiapan sudah dijalankan dengan baik saat pra produksi, sebetulnya saat produksi bukan hal yang sulit. Set baik studio atau non studio harus sudah siap untuk digunakan shooting. Rehearsal atau latihan sebaiknya dilakukan di lokasi shooting, hal ini untuk memudahkan koreksi jika ada perubahan atau apapun kebutuhan produksi tersebut.

Setidaknya ada dua cara bagaimana produser 
menggunakan sumber daya manusia atau crew yang akan dilibatkan dalam produksi acara televisi. Pertama dengan membangun crew, yakni benarbenar menentukan crew siapa saja yang akan dilibatkan. Kedua dengan menyusun crew, lantas meminta sumber daya tersebut pada department support. Yang paling banyak dilakukan adalah dengan cara kedua, karena hampir semua stasiun televisi mmeiliki departemen support yang akan mensuplai crew yang dibutuhkan dalam kegiatan produksi.Paska produksi merupakan gerbang terakhir dari pembuatan acara televisi. Materi hasil shooting diberikan pada departemen paska produksi.Sebelumnya, produser memberikan arahan pada chief editor tentang konsep acara yang dibuat. Menyunting gambar bukan sekadar memotong dan menyambung gambar. Lebih dari itu editor baiknya punya rasa seni juga, sehingga hasil yang akan ditayangkan bukan sambungan atau potongan mekanis saja. Editor merupakan story teller, ia harus mampu bertutur dengan bahasa gambar. Sebanyak 32 anak hebat dari seluruh Indonesia akan beradu kemampuan dalam menghafalkan dan melafalkan ayat-ayat suci dan melewati 5 tahap, yaitu tahap salamah (audisi), tahap muqadimah (perkenalan), tahap Izaalah (eliminasi), tahap Musabaqah (perlombaan) dan babak terakhir, Wisuda Akbar. Dibawakan oleh Irfan Hakim dan empat juri; Syeikh Ali Jaber, Prof. Dr. Nasaruddin Umar, Prof. Dr. Amir Faishol Fath dan Ustadzah Lulu Susanti.

Strategi Programing yang terjadi di RCTI, di mana sangat mempengaruhi Program Acara Hafiz Indonesia. Terlihat dari program yang ditayangkan pada waktu Morning Time 05.00 WIB - 08.59 WIB (audiens Kelas A-B, semua umur atau jumlah audiens banyak) dengan perkiraan banyak audiens anak-anak yang menonton maka dimulai dari pukul 06.00 hingga 08.30 RCTI mengisinya dengan tayangan khusus liburan berformat kartun dan fantasi. Strategi lainnya yang digunakan oleh RCTI adalah Tentpoling yaitu langkah perencanaan slot waktu bagi program acara yang baru, sebelum dan setelah program ungulan yang mempunyai audiens cukup besar seperti program acara "Hafiz Indonesia".

Proses perencanaan program Hafiz Indonesia
RCTI dilakukan secara bergotong royong tidak hanya oleh divisi programing saja, dimulai dari program analyst. Mereka terdiri dari divisi programing dan orang-orang lainnya yang tergabung dalam komite program. Program analyst memberikan ide dan garis-garis besar mengenai program Acara HafizIndonesia apa yang sebaiknya dibuat. Setelah itu, disampaikanlah kepada program maker untuk merencanakan program seperti apakah yang akan dibuat, konsep, tujuan serta temanya." Perencanaan program juga terkait dengan kemampuan teknik dan administrasi yang harus mampu mendukung kelancaran proses produksi dan siaran, karena output organisasi penyiaran adalah siaran program acara.

Berkaitan dengan tahap pra produksi Erwin Amirul sebagai informan pertama, menjelaskan bahwa: "Pada tahap ini produser akan mengemukakan perkiraan susunan acara yang bersifat fleksibel dan dapat berubah tergantung perkembangan acara pada saat berlangsungnya program, namun tidak keluar dari konsep awal yang telah disepakati. Pada tahap ini terjadi interaksi antara kreativitas dan peralatan pendukung yang tersedia.Sebelum memulai tahap produksi, produser program memimpin rapat dengan seluruh crew untuk membahas susunan acara (rundown). Erwin Selaku informan pertama menjelaskan mengenai tahapan produksi. Pada tahap produksi koordinasi antara produser dengan floor director berlangsung selama berjalannya proses produksi untuk mengkoordinasikan dengan semua kerabat yang bertugas. Floor director merupakan pimpinan di studio, di beberapa stasiun televisi, floor director biasa disebut sebagai floor manager.Floor director adalah kepanjangan tangan dari Program Director atau $P D$.

Secara umum tahap paska produksi ini dikenal dengan tahap editing video, meski pada kenyataannya banyak unsur pekerjaan lain yang terlibat, misalnya pembuatan animasi dan visual efek, sound engineering dan image editing. Keseluruhan tahap ini untuk memaksimalkan hasil gambar. Erwin sebagai informan pertama menjelaskan mengenai tahap paska produksi Program Hafiz Indonesia yaitu pada tahap ini, produser memiliki tanggungjawab untuk memilih 
editor sebagai penanggungjawab pada saat melakukan tahap editing.

Evaluasi program merupakan bentuk kegiatan terakhir programing. Pada tahap ini, programmer harus mampu membaca situasi dan melihat performa program. Hal ini bertujuan untuk terus menarik dan mempertahankan jumlah pemirsa sebanyak mungkin. Dalam evaluasi program Acara Hafiz Indonesia Ini ini juga dilihat sejauh mana program-program yang ditampilkan mampu mencapai tujuan yang ditetapkan.

\section{SIMPULAN}

Setelah melihat strategi yang digunakan oleh RCTI yaitu strategi stripping pada saat jumlah audiens besar dan strategi checker boarding pada saat jumlah audiens mengalami penurunan, namun RCTI juga menggunakan strategi tentpolinguntuk memperkenalkan program barunya. Penciptaan program Hafiz Indonesia bertujuan untuk memberikan tayangan alternatif bagi anak - anak. Program televisi Hafiz Indonesia menampilkan anak - anak muda berbakat dalam menghafal AlQuran tanpa ada skenario atau naskah. Jadi para peserta menampilkan dirinya di layar televisi dengan apa adanya. Ini memberikan inspirasi kepada teman sebayanya untuk menghafalkan AlQuran.

Adapun perencanaan dan pengemasan acara program Hafiz Indonesia pada yaitu: Proses perencanaan program Hafiz Indonesia 2014, RCTI di Jakarta dilakukan secara bergotong royong tidak hanya oleh divisi programing saja, dimulai dari program analyst. Mereka terdiri dari divisi programing dan orang-orang lainnya yang tergabung dalam komite program, termasuk Produser dan tim produksi. Kegiatan pra produksi akan ditayangkan dan dimulai dengan penuangan ide atau gagasan ke dalam outline yang berisikan gambaran program suatu acara. Narasumber yang dipilih adalah orang yang memiliki kredibilitas dan mengetahui dengan pasti mengenai topik yang akan dibahas. Pengemasan program yang dilakukan editor harus selalu berbeda, artinya di setiap episode ada sebuah hal yang menarik yang membuat penonton ingin terus menyaksikan program ini, mungkin itu dari caraeditor menyambung gambar demi gambar, pemilihan warna dan pengaturan suara.Dalam hal ini proses komunikasi organisasi yang terjadi di acara Hafiz Indonesia adalah atasan dan bawahan, mereka saling memahami satu sama lain kebutuhan yang dilakukan setiap acara, saling membantu apabila masing- masing jobdesk mereka telah terselesaikan dan membutuhkan bantuan, sehingga kerja sama sebagai modal kunci keberhasilan dalam organisasi Struktur Kerabat Kerja Hafiz Indonesia. Hafiz Indonesia bukan hanya sebuah tontonan tapi juga tuntunan, selain menghibur juga dapat mendidik generasi muda dengan menebar virus positif untuk masyarakat Indonesia.

Program Hafiz Indonesia semoga mampu mempertahankan eksistensinya menjadi program unggulan special Ramadhan terbaik, terdepan yang dapat menginspirasi masyarakat luas, khususnya generasi muda penghafal Al-Quran. Selain itu konten-konten per segment dibikin sevariatif mungkin dan selalu mencerminkan program bergenre religi yang tidak hanya disukai anak-anak tapi juga disukai masyarakat umum kelas A-B-C. Menyelenggarakan roadshow diberbagai daerah dan kota-kota besar yang mewakili target audiens. Selain melakukan audisi di taman kanak-kanak (TK) dan Sekolah Dasar (SD), diharapkan Tim Audisi "Hafiz Indonesia" dapat melakukan audisi dipesantren-pesantren yang tersebar diseluruh pelosok Indonesia yang notabenya memiliki santrisantri cilik penghafal Al-Qur'an .

\section{DAFTAR PUSTAKA}

Fred Wibowo. 2007. Teknik Produksi Program Televisi. Yogyakarta: Pinus Book Publisher.

Hertika Yudha Pratiwi, Jurnal FISIP UI 2014. "Strategi Kompetisi Programming Stasiun TV Swasta Nasioal", Analisisi Terhadap RCTI dan SCTV.

Jauch, Lawrence. R dan Glueck, William 1998. Manajemen Strategis dan Kebijakan Perusahaan. Terjemhan Murad dan Henry Sitanggang, Erlangga, Jakarta

Littlejohn, Stephen W \& Foss, Karen A.
2005. Theories of $H u m a n$ 
Communication, $8^{\text {th }}$ edition, USA, Thomson Wadsworth Chapter 9.

Loncoln dan Denzim (ed). 1994. Hand Book of Qualitative Research, Sage Publication. Thousan oaks, London.

Naratama, 2004. Menjadi Sutradara Televisi, Gramedia, Palmerah, Jakarta.

Quail, Denis. 1985. Model-Model Komunikasi. Alih Bahasa Putu Laxman Pendit. Jakarta: Uni Primas

Rusman Latief, Yusiantie Utud. 2015. Siaran Televisi Non-Drama. Kreatif, Produksi, Public Relation, dan Iklan. Kencana, Rawamangun, Jakarta.

RCTI, Visi, Misi dan 3 Pilar Utama /2012/06/ definisi-peran-dan-fungsi-mahasiswa. htmlhttp://pengertianpengertian.blogspot. com/2012/10/pengertian-kebiasaan. htmlhttp://id.wikipedia.org/wiki/Dosen

http://pls.upi.edu/index.php/pls-profil/sdm/ tupoksi-plshttp://www.smkn3tarakan. net $/$ index.php? option $=\mathrm{com}$ content\&view $=$ article $\&$ id $=164$ :perananmotivasi-dalam-belajar\&catid $=1$ : latestnews

(http://rcti.televisi/profile/view/2/Visi--Misi-Dan3-Pilar-Utama diakses Juni 2015RCTI, Profile Perusahaan. (http://rcti.televisi/ profile/view/1 diakses Juni 2015) 